\title{
Physical Identification of Bacteriocinogenic, Nodulation and Other Plasmids in Strains of Rhizobium leguminosarum
}

\author{
By P. R. HIRSCH, ${ }^{1}$ M. VAN MONTAGU, ${ }^{2}$ A. W. B. JOHNSTON, ${ }^{3 *}$ \\ N. J. BREWIN ${ }^{3}$ AND J. SCHELL ${ }^{1}$ \\ ${ }^{1}$ Max-Planck-Institut für Züchtungsforschung, D-5000 Köln-Vogelsang 30, W. Germany \\ ${ }^{2}$ Laboratories for Histology and Genetics, State University Gent, K. L. Ledeganckstraat 35, \\ B-9000 Gent, Belgium \\ ${ }^{3}$ John Innes Institute, Colney Lane, Norwich NR4 7UH
}

(Received 11 April 1980)

Plasmids obtained from four field isolates of Rhizobium leguminosarum were visualized following electrophoresis on agarose gels. The relative mobilities of the bands observed corresponded to plasmids with molecular weights of about $100 \times 10^{6}$ and greater. Each field isolate examined had a different pattern of plasmids.

Lysates from $R$. leguminosarum strain 300 normally produced three plasmid bands, although in some preparations two much larger plasmids were also visible. The smallest plasmid band seen in strain 300 probably contains two co-migrating plasmids, because in one derivative of strain 300 it was replaced by a doublet, presumably as a result of the presence of a small deletion in one of the co-migrating plasmids. No apparent symbiotic defects were associated with the presence of this deletion. However, a non-nodulating derivative of strain 300 (strain 6015) was found to have suffered a deletion in the thirdsmallest plasmid of this strain.

Transfer of the determinant of medium-sized bacteriocin production pRL1JI (from isolate 248) was correlated with the appearance of an extra plasmid with a molecular weight of about $130 \times 10^{6}$. Another determinant of medium bacteriocinogenicity, pRL4JI (from isolate 309), was correlated with the presence of an extra plasmid of the same size (about $160 \times 10^{6}$ ) as one seen in the donor strain 309. The third determinant, pRL3JI (from isolate 306), could not be correlated with the presence of an extra plasmid of the same size as any in strain 306, and it appears that recombination occurred between pRL3JI and plasmids resident in strain 300 .

\section{INTRODUCTION}

There is recent evidence that plasmids play an important role in determining the ability of Rhizobium to induce nitrogen-fixing nodules on legume roots. Large plasmids (molecular weights greater than $10^{8}$ ) have been found in several Rhizobium species (Nuti et al., 1977; Casse et al., 1979; Prakash et al., 1980). Loss of one large plasmid from a strain of $R$. leguminosarum was associated with loss of the ability to nodulate peas (Casse et al., 1979; Prakash et al., 1980). Evidence that at least some of the structural genes for nitrogenase (nif genes) are present on Rhizobium plasmids came from the demonstration that cloned nif DNA isolated from Klebsiella pneumoniae hybridized specifically to Rhizobium plasmid DNA (Nuti et al., 1979; Ruvkun \& Ausubel, 1980).

Hirsch (1979) reported high frequency conjugal transfer of the ability to produce mediumsized bacteriocins from three different $R$. leguminosarum field isolates to other strains of 
$R$. leguminosarum. This transfer was associated with the transfer of chromosomal markers at much lower frequencies. The three presumptive bacteriocinogenic plasmids found in field isolates 248,306 and 309 were named pRL1JI, pRL3JI and pRL4JI, respectively.

When pRL1JI, or a derivative into which the transposon Tn5 had been inserted, was transferred to a number of symbiotically defective derivatives of $R$. leguminosarum strain 300 , the transconjugants gained the ability to form effective nodules on peas (Johnston et al., 1978; Brewin et al., 1980). The mutants used included strains that failed to nodulate $\left(\mathrm{Nod}^{-}\right)$or which induced nodules that did not fix nitrogen (Fix ${ }^{-}$), suggesting that pRL1JI carries more than one gene important in the symbiosis.

The transposon Tn5 was inserted into pRL1JI by the method of Beringer et al. (1978a) and when this plasmid (pJB5JI) was introduced into $R$. trifolii and $R$. phaseoli, two species that do not normally nodulate peas, the transconjugants acquired the ability to nodulate this host (Johnston et al., 1978). However, when pRL3JI or pRL4JI was transferred to the symbiotically defective mutants that were suppressed by pRL1JI, no individual transconjugants were restored to symbiotic proficiency (Brewin et al., 1980).

In this paper we report the physical demonstration of these bacteriocinogenic plasmids and of the plasmids present in the genetically well-characterized $R$. leguminosarum strain 300 (Beringer et al., 1978b) and some of its derivatives.

\section{METHODS}

Bacterial strains and plasmids. These are shown in Table 1.

Bacterial manipulations. Culture conditions, bacterial crosses, plant nodulation tests and screening for bacteriocin production were described by Beringer (1974) and by Brewin et al. (1980).

Growth media. Liquid TY medium contained $0.5 \%$ (w/v) Difco Bacto-Tryptone, 0.3\% (w/v) Difco Bacto-Yeast Extract and $7 \mathrm{~mm}-\mathrm{CaCl}_{2}$. Liquid PA medium contained $0.4 \%(\mathrm{w} / \mathrm{v})$ Difco Bacto-Peptone and $2 \mathrm{mM}_{-} \mathrm{MgSO}_{4}$. Rhizobium leguminosarum strains grew poorly in PA medium, never giving very turbid cultures, but this was found to be an advantage in obtaining good lysis and plasmid preparations.

Buffers. TE buffer was $50 \mathrm{~mm}$-Tris/HCl with $20 \mathrm{~mm}$-EDTA, pH $8 \cdot 0$. Dialysis buffer was $10 \mathrm{~mm}$-Tris/ $\mathrm{HCl}$ with $1 \mathrm{~mm}$-EDTA, pH 8.0. Tris/borate electrophoresis buffer contained (per litre); $10.8 \mathrm{~g}$ Tris, $0.93 \mathrm{~g}$ EDTA and $5 \cdot 5 \mathrm{~g}$ boric acid, $\mathrm{pH} 8 \cdot 3$.

Isolation of large plasmids. The protocol for small-scale crude plasmid preparation was as follows: $200 \mathrm{ml}$ PA medium was inoculated with $2 \mathrm{ml}$ of a stationary phase stock culture of $R$. leguminosarum (in TY) or A. tumefaciens (in PA) and shaken at $28^{\circ} \mathrm{C}$ for about $36 \mathrm{~h}$. Bacteria were harvested at a final concentration of about $10^{8}$ viable bacteria $\mathrm{ml}^{-1}$, washed in TE buffer and resuspended in $16 \mathrm{ml}$ TE buffer. Then $2 \mathrm{ml}$ Pronase (Sigma Pronase P, $5 \mathrm{mg} \mathrm{ml}^{-1}$ in TE buffer, pre-digested $1 \mathrm{~h}$ at $37^{\circ} \mathrm{C}$ ) and $2 \mathrm{ml}$ sodium dodecyl sulphate (SDS; $10 \%$, w/v, in TE buffer) were added and the mixture was incubated at $37^{\circ} \mathrm{C}$ with gentle shaking for $1 \mathrm{~h}$ or until lysis was complete. The clear, viscous lysate was adjusted to $\mathrm{pH} 12.4$ by addition of $3 \mathrm{M}-\mathrm{NaOH}$ (about $0.5 \mathrm{ml}$ ) with gentle but thorough stirring, using a plastic rod or pipette. After standing at room temperature for $30 \mathrm{~min}$, the lysate was adjusted to $\mathrm{pH} 8.5$ with $2 \mathrm{M}$-Tris/ $\mathrm{HCl}$, $\mathrm{pH} 7.0$ (about 1.5 $\mathrm{ml}$ ) and transferred to a $40 \mathrm{ml}$ centrifuge tube. Then $5 \mathrm{M}-\mathrm{NaCl}$ was added to give a final concentration of $1 \mathrm{~m}$; the contents of the tube were mixed by gentle inversion and left on ice for at least $4 \mathrm{~h}$. The SDS/NaCl complex was precipitated by centrifugation at $10000 \mathrm{rev} \cdot \mathrm{min}^{-1}$ for $20 \mathrm{~min}$ at $4{ }^{\circ} \mathrm{C}$. The supernatant was carefully decanted to a fresh tube, and $50 \%(\mathrm{w} / \mathrm{v})$ polyethyleneglycol (PEG) 6000 was added to give a final concentration of $10 \%$; the contents of the tube were mixed by gentle inversion and left on ice overnight. The DNA was precipitated by centrifuging at $7000 \mathrm{rev}$. $\min ^{-1}$ at $4{ }^{\circ} \mathrm{C}$ for $15 \mathrm{~min}$. The supernatant was discarded and the pellet was resuspended in $0.5 \mathrm{ml} \mathrm{TE}$ buffer containing $0.1 \%(\mathrm{v} / \mathrm{v})$ diethylpyrocarbonate to inhibit nuclease activity. The samples were stored at $4{ }^{\circ} \mathrm{C}$.

For large-scale plasmid preparations, the volumes were increased 10 -fold and $4.5 \mathrm{ml}$ of the DNA solution was added to a solution of $30 \mathrm{~g} \mathrm{CsCl}$ dissolved in $25 \mathrm{ml}$ TE buffer, followed by $2.6 \mathrm{ml}$ ethidium bromide $\left(10 \mathrm{mg} \mathrm{ml}^{-1}\right)$. The remaining crude plasmid preparation was retained to test directly for the presence of plasmids on gels. The solution was mixed by gentle inversion, then centrifuged in a swinging bucket rotor for $10 \mathrm{~min}$ at $5000 \mathrm{rev} . \mathrm{min}^{-1}$ at $4^{\circ} \mathrm{C}$ and the resultant skin (of residual PEG 6000) was removed before transferring the solution to a polycarbonate ultracentrifuge tube $(40 \mathrm{ml}$ capacity) and centrifuging in a Beckman VTi50 rotor for $18 \mathrm{~h}$ at $40000 \mathrm{rev} . \mathrm{min}^{-1}$ at $15^{\circ} \mathrm{C}$. The gradient was illuminated with u.v. light $(366 \mathrm{~nm})$ and the lower band corresponding to plasmid DNA was removed from the side of the tube with a 


\section{Table 1. Bacterial strains and plasmids}

Strain

Agrobacterium tumefaciens C58

Rhizobium
leguminosarum
Field isolates
248
306
309
300

Derivatives of strain 300 897

$$
\begin{aligned}
& 1027 \dagger \\
& 1062 \\
& 6015
\end{aligned}
$$

\author{
Relevant characteristics
}

Harbours the Ti plasmid pTiC58

\section{Reference}

Watson et al. (1975)
Josey et al. (1979)

Josey et al. (1979)

Josey et al. (1979)

Johnston \& Beringer (1975)

Johnston \& Beringer (1976)

Brewin et al. (1980)

Johnston et al. (1978)

Johnston et al. (1978)

Properties determined

\begin{tabular}{llccll} 
& \multicolumn{5}{c}{ Properties determined } \\
Plasmid $\$$ & $\begin{array}{c}\text { Production of } \\
\text { medium } \\
\text { bacteriocin }\end{array}$ & $\begin{array}{c}\text { Kanamycin } \\
\text { resistance }\end{array}$ & Nod $^{+}$ & \\
pRL1JI & Strain 248 & + & - & + & Johnston et al. (1978) \\
pRL3JI & Strain 306 & + & - & - & Hirsch (1979) \\
pRL4JI & Strain 309 & + & - & - & Hirsch (1979) \\
pJB5JI & pRL1JI & - & + & + & Johnston et al. (1978)
\end{tabular}

* $\mathrm{Nod}^{+}$, strain induces nodules on peas; $\mathrm{Fix}^{+}$, strain induces nodules on peas which fix nitrogen.

$\dagger$ Nod $^{-}$phenotype caused by ade mutation (Pain, 1979).

$\ddagger$ Defined by genetic criteria, i.e. linked transfer of the properties determined.

syringe. Ethidium bromide was removed from the sample by five extractions with 2 vol. of cold 2-propanol saturated with $\mathrm{CsCl} / \mathrm{TE}$ buffer, and the sample was dialysed against four changes of dialysis buffer at $4{ }^{\circ} \mathrm{C}$ (1 1 each time, minimum $4 \mathrm{~h}$ between changes) to remove $\mathrm{CsCl}$.

All buffers, solutions, glassware, etc. were sterilized by autoclaving or rinsing with $75 \%$ ethanol to reduce the risk of contamination with nucleases.

Agarose gel electrophoresis. A horizontal Perspex apparatus giving a gel slab $13.3 \mathrm{~cm}$ wide, $14 \mathrm{~cm}$ long and $0.6 \mathrm{~cm}$ thick was used. Sample wells were formed using a Perspex comb with nine teeth. Samples of crude plasmid preparations were centrifuged for $2 \mathrm{~min}$ in an Eppendorf 5412 centrifuge and $40 \mu \mathrm{l}$ of the supernatant (or $40 \mu$ l plasmid preparations purified on $\mathrm{CsCl}$ gradients) was added to $10 \mu$ loading dye [ $20 \%$ (w/v) Ficoll 400, 0.125\% (w/v) bromophenol blue, $50 \mathrm{~mm}$-EDTA] and loaded on the gel. Electrophoresis was performed on $0.7 \%(\mathrm{w} / \mathrm{v})$ Agarose (Seakem) in Tris/borate buffer, at $45 \mathrm{~mA}(180 \mathrm{~V})$ and $4{ }^{\circ} \mathrm{C}$ for $6 \mathrm{~h}$. The gel slab was then removed from the apparatus and stained for $20 \mathrm{~min}$ in Tris/borate buffer containing ethidium bromide $\left(0.5 \mu \mathrm{g} \mathrm{ml}^{-1}\right)$, removed and stored at $4{ }^{\circ} \mathrm{C}$ for $4 \mathrm{~h}$ before visualizing the plasmid bands (storage was found to enhance the visualization of faint bands and reduce the background fluoresence). The gel was illuminated under u.v. light $(366 \mathrm{~nm})$ to visualize the plasmid bands, and photographed using a Polaroid Land camera with Polaroid type 55 film.

\section{RESULTS}

\section{Plasmid isolation}

Several methods for the isolation of large plasmids with molecular weights greater than $10^{8}$ have been reported (Zaenen et al., 1974; Ledeboer et al., 1976; Currier \& Nester, 1976; Nuti et al., 1977; Hansen \& Olsen, 1978; Casse et al., 1979). The method used here was a modification of a protocol developed at the Rijksuniversiteit, Gent by R. Villaroel and 


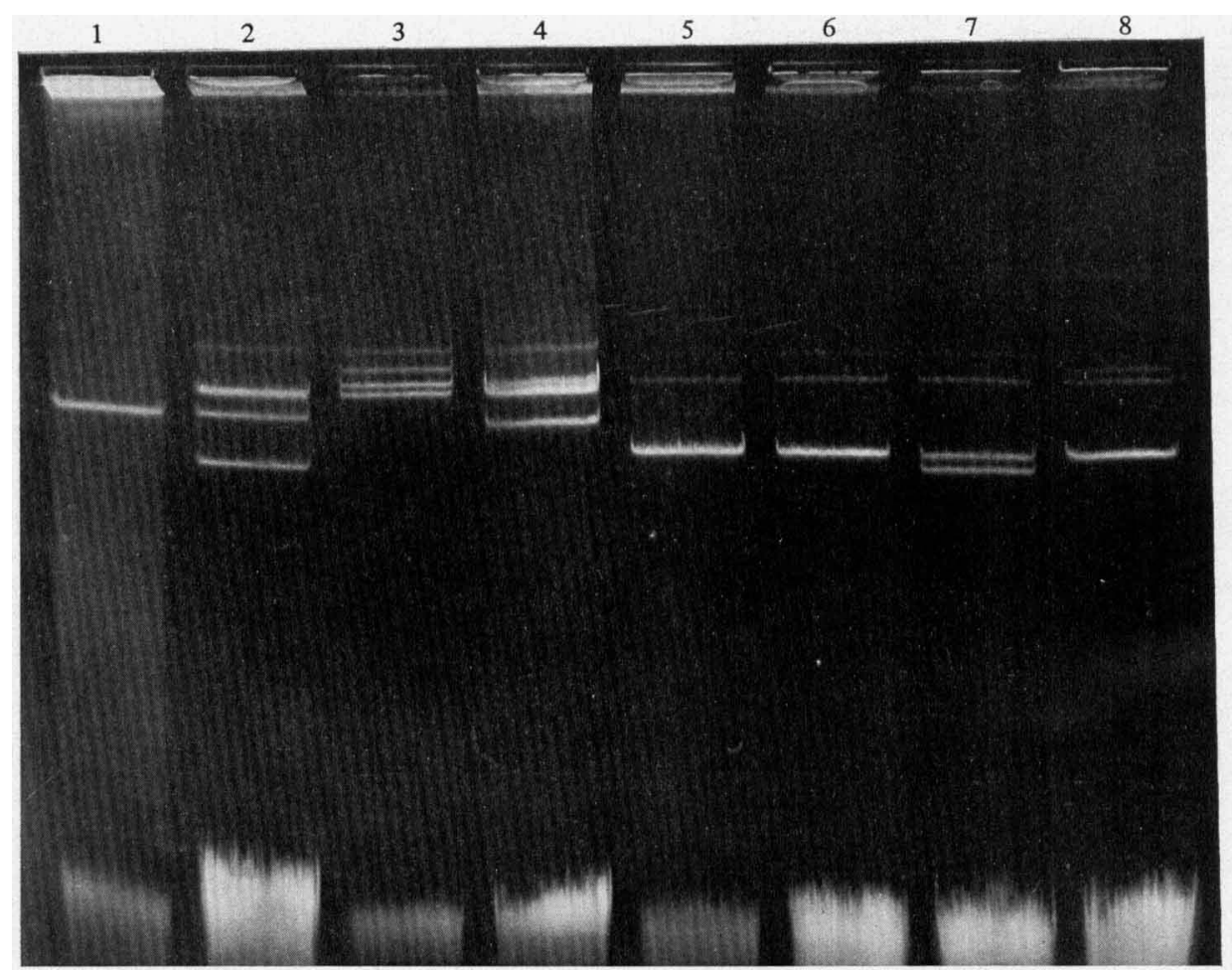

Fig. 1. Rhizobium leguminosarum plasmids and reference Agrobacterium tumefaciens plasmid after agarose gel electrophoresis. Track 1 , strain C58; 2, 248; 3, 306; 4, 309; 5, 897; 6, 1027; 7, 1062; 8, 6015 .

J. Ellis (personal communication). It was simple and reproducible, giving discrete fluorescent bands when the gels were stained with ethidium bromide and examined under u.v. light (Fig. 1).

The discrete bands observed after electrophoresis of crude plasmid preparations were assumed to represent covalently closed circular (ccc) plasmid DNA of various sizes and the diffuse fluorescing band, which migrated much further, to represent linear DNA fragments (Fig. 1). This was confirmed by scaling up the crude preparation protocol 10-fold for strains C58, 248, 897 and 6015 and subjecting the resuspended DNA following PEG 6000 precipitation to centrifugation on $\mathrm{CsCl} /$ ethidium bromide density gradients. The lower band, corresponding to ccc DNA, was recovered from each gradient and, after removal of ethidium bromide and $\mathrm{CsCl}$, the DNA was run on agarose gels. The bands (not shown) corresponded to those obtained from crude preparations although the slowermigrating bands were relatively faint compared with the fastest-migrating band for samples recovered from $\mathrm{CsCl}$ gradients, indicating a greater loss of the larger plasmids during density gradient centrifugation and subsequent purification. The fast-migrating diffuse zone of linear DNA was absent or very faint in samples recovered from $\mathrm{CsCl}$ gradients (not shown). The fluorescence observed under u.v. light at and just beyond the wells (Fig. 1) may be due to open circular forms of the large plasmids.

\section{Comparison of plasmids in derivatives of $R$. leguminosarum strain 300 with the Ti plasmid from A. tumefaciens strain C58}

Strain 897 (a derivative of strain 300 ) has been reported to have three plasmids with molecular weights of about $100 \times 10^{6}, 165 \times 10^{6}$ and $204 \times 10^{6}$ (Prakash et al., 1980). The Ti plasmid of strain C58, pTiC58, has a molecular weight of about $130 \times 10^{6}$ (Holsters 
et al., 1978). The relative mobilities of the bands of strains 897 and C58 (Fig. 1, tracks 5 and 1) are compatible with plasmids of these sizes migrating at rates approximately inversely proportional to the logarithms of their molecular weights. Casse et al. (1979) showed a linear relationship between the logarithms of the molecular weights and relative mobilities of ccc plasmid DNA in the range of $91 \times 10^{6}$ to $140 \times 10^{6}$ molecular weight.

The field isolate from which strain 897 was obtained, strain 300 (not shown), and a different auxotrophic derivative, strain 1027 (Fig. 1, track 6), gave identical band patterns to strain 897 . However, another auxotrophic derivative of strain 300 , strain 1062 , had an extra band that migrated faster than the fastest plasmid band of strain 897 , implying that strain 1062 has acquired a new plasmid species with a molecular weight of less than $100 \times 10^{6}$ (Fig. 1, track 7). It is possible that strains 300,897 and 1027 have two different plasmids of molecular weights about $100 \times 10^{6}$ and that strain 1062 has suffered a small deletion in one of them, although phenotypically it appears to differ from the other strains only in auxotrophic requirements and antibiotic resistances that map to the chromosome (with the exception of strain 1027, which has an adenine requirement, these strains induced nodules on peas which fixed nitrogen). Consistent with this hypothesis is the observation that the fastest-migrating band in strains 897,1027 and 6015 was consistently brighter (relative to their slower-migrating bands) than either of the two fast-migrating bands of strain 1062 (Fig. 1).

In addition to the plasmid bands seen in Fig. 1, we have also seen, in a minority of preparations, one, and sometimes two, additional bands moving more slowly than the slowest-migrating band described here.

Strain 6015 is a mutant of strain 300 which has lost the ability to form nodules, and it has never been found to revert (frequency $<10^{-9}$ ). The slowest-migrating band of strain 6015 was found to migrate faster than that of strains 897,1027 or 1062 , implying a deletion in the largest plasmid (molecular weight $204 \times 10^{6}$ ) of a region containing genes involved in nodulation (Fig. 1, track 8).

Prakash et al. (1980) named the plasmids that they isolated from a derivative of strain 300: pRle-LPR115a, pRle-LPR115b and pRle-LPR115c in order of increasing size. Since we have observed variations in the sizes and numbers of plasmid species present in different derivatives of strain 300 , we have deliberately omitted to name them until more is known of the relationships between the plasmids.

\section{Identification of bacteriocinogenic plasmids}

In attempts to identify the plasmid bands corresponding to pRL1JI, pRL3JI and pRL4JI, the plasmids found in the field isolates 248, 306 and 309 were compared with those of transconjugants of various strain 300 derivatives which had received one of the bacteriocin determinants. It can be seen that the plasmid bands of strains 248, 306 and 309 (Fig. 1, tracks 2, 3 and 4, respectively) differ from each other and from strain 300 or some of its derivatives (e.g. tracks 5 and 6).

\section{pRL1JI}

When pRL1JI-determined bacteriocin production was transferred to strain 300 derivatives (strains 1062, 1027 and 6015) the transconjugants were found to have gained a band corresponding in size to the second smallest plasmid in strain 248 (Fig. 2, track 2) whether bacteriocinogenicity had been transferred either directly from strain 248 (Fig. 2, tracks 3 and 9) or from a derivative of strain 300 that had acquired the plasmid (Fig. 2, tracks 5 and 6). This extra band corresponding to pRL1JI showed the same relative mobility as pTiC58 which has a molecular weight of $130 \times 10^{6}$ (Holsters et al., 1978). Derivatives of strain 6015 which had received pRL1JI from strain 248 or strain 1062 (pRL1JI) gained the 


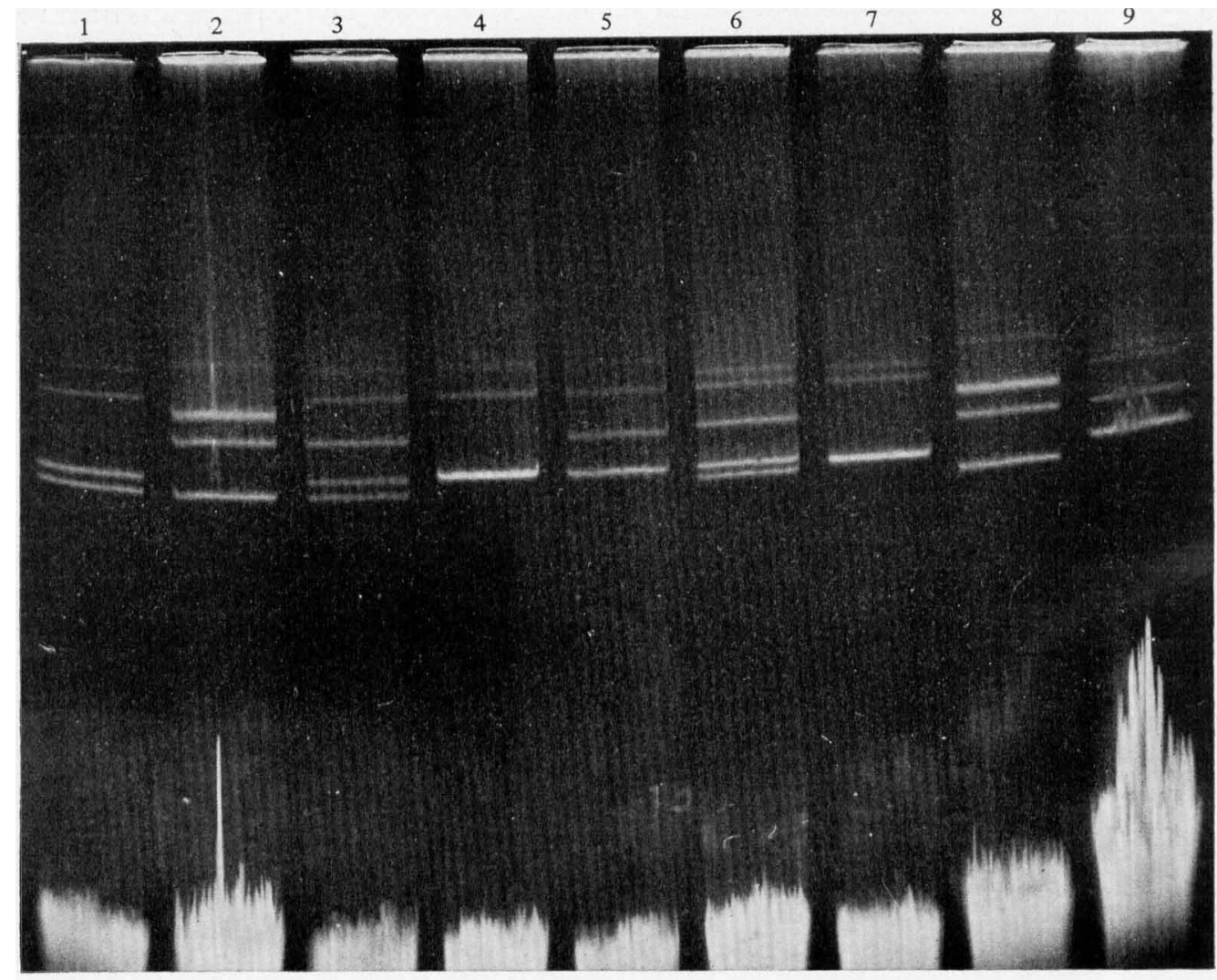

Fig. 2. Plasmids of $R$. leguminosarum pRL1JI transconjugants after agarose gel electrophoresis. Track 1 , strain $1062 ; 2,248 ; 3,1062(\mathrm{pRL} 1 \mathrm{JI})$, donor $248 ; 4,1027 ; 5,1027(\mathrm{pRL} 1 \mathrm{JI})$, donor 1062(pRL1JI); 6, 6015(pRL1JI), donor 1062(pRL1JI); 7, 6015; 8, 248; 9, 6015(pRL1JJ), donor 248.

ability to nodulate peas (Brewin et al., 1980) and we therefore conclude that pRL1JI, defined as the conjugative plasmid determining medium-sized bacteriocin production linked to genes involved in symbiosis, has a molecular weight of about $130 \times 10^{6}$.

Strains carrying pJB5JI, a plasmid obtained by the insertion of Tn5 into pRL1JI (Johnston et al., 1978), were found to have a plasmid band with the same relative mobility as pRL1JI (data not shown). This is not unexpected since Tn5 which has a molecular weight of about $3.8 \times 10^{6}$ (Berg et al., 1975), would cause only a very slight proportional increase in the size of $\mathrm{pRL} 1 \mathrm{JI}$.

One derivative of strain 6015 which had received pRL1JI from strain 1062(pRL1JI) had, in addition, an extra band corresponding to the smallest plasmid in strain 1062 (Fig. 2, track 6). This could have been due to mobilization of the strain 1062 plasmid by pRL1JI, a phenomenon observed in crosses to other strains of $R$. leguminosarum (N. J. Brewin, unpublished observations) and to $R$. phaseoli (J. L. Beynon, personal communication).

It was noted that in the transconjugant that had apparently received the smallest strain 1062 plasmid (Fig. 2, track 6), the second smallest band stained less intensely than did the band of corresponding size in the strain 6015 parent (Fig. 2, track 7). This is consistent with strain 6015 having received a plasmid that is incompatible with the one of the two plasmids in the strain 1062 doublet (see above). 


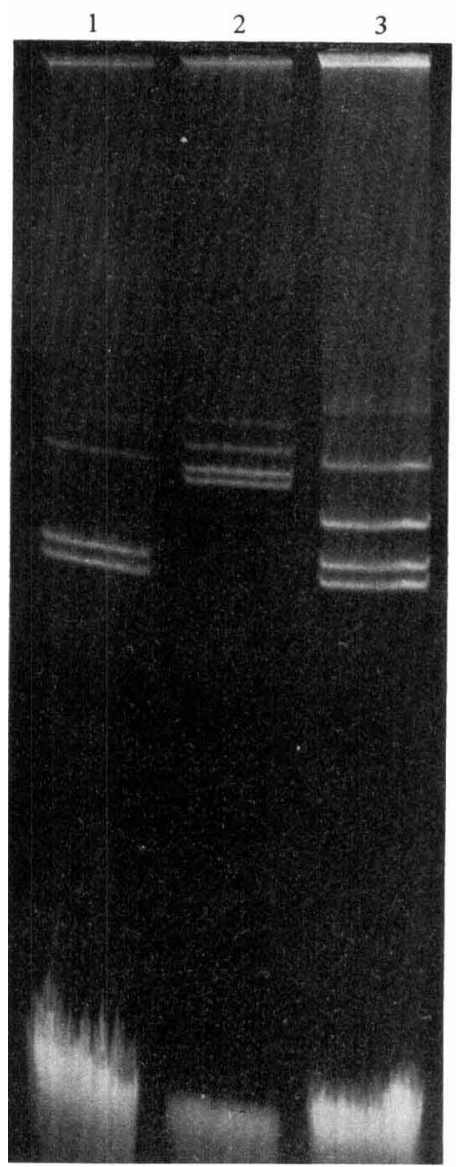

Fig. 3

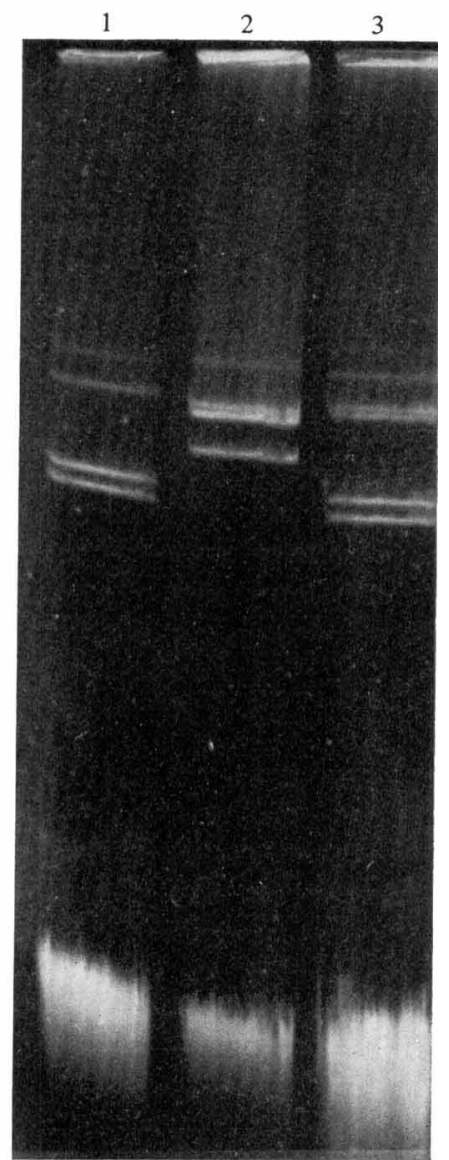

Fig. 4

Fig. 3. Plasmids of $R$. leguminosarum pRL3JI transconjugants after agarose gel electrophoresis. Track 1, strain 1062; 2, 306; 3, 1062(pRL3JI), donor 306.

Fig. 4. Plasmids of $R$. leguminosarum pRL4JI transconjugants after agarose gel electrophoresis. Track 1, strain 1062; 2, 309; 3, 1062(pRL4JI), donor 309.

\section{pRL3JI}

The bacteriocinogenic determinant transferred from field isolate 306 was designated pRL3JI (Hirsch, 1979). Strain 306 appears to have at least four large plasmids, of which the smallest is larger than pTiC58 (Fig. 1, tracks 1 and 3). Strain 6015(pRL3JI), which had received the determinant of medium bacteriocin production from strain 306 , had acquired a new plasmid species slightly smaller than the second smallest plasmid in strain 6015 (data not shown) which corresponded in size to the second smallest plasmid in strain 306 . However, strain 1062(pRL3JI) which had received the determinant of medium bacteriocin production from strain 306 showed no bands corresponding to any of those in strain 306 (Fig. 3, tracks 2 and 3). Two changes were apparent in this transconjugant: a new plasmid appeared with a molecular weight of about $130 \times 10^{6}$ (its relative mobility was the same as that of pTiC58 and pRL1JI in several gels, which are not shown); and an even larger plasmid replaced the largest one usually visible in strain 1062 (Fig. 3, tracks 1 and 3). This could be explained by unequal recombination of pRL3JI with a strain 1062 plasmid. Because recombination between these plasmids occurs it is not yet possible to correlate the genetic determinant of bacteriocinogenicity, pRL3JI, with a distinct plasmid species. 


\section{pRL4JI}

Strain 309 is another field isolate which can donate the ability to produce a medium bacteriocin (Hirsch, 1979) and this strain appeared to have at least four plasmids (Fig. 1, track 4). When the determinant of medium bacteriocinogenicity, pRL4JI, was transferred from strain 309 to strain 1062, a new plasmid band was observed corresponding in size to the third-smallest plasmid of strain 309 (Fig. 4, tracks 2 and 3); this was also present in derivatives of strains 6015 and 1027 which had received pRL4JI from strain 1062(pRL4JI) (data not shown). The mobility of this plasmid was very similar to that of the third-smallest plasmid species in strain 1062 (or the second-smallest plasmid species in strains 1027 and 6015). However, a derivative of strain 6015 which had received the determinant of medium bacteriocinogenicity directly from strain 309 appeared to have a new plasmid species smaller than the smallest in strain 309 and larger than the smallest in strain 6015 (data not shown). This could be a deleted derivative, which retained the region determining production of the medium bacteriocin, of the plasmid observed in other strains carrying pRL4JI. Only one transconjugant clone was examined from each of the crosses described above.

\section{DISCUSSION}

We have demonstrated, by physical means, the presence of some plasmids in $R$. leguminosarum which had previously been defined only by genetic criteria. We have shown that strain 6015 , a derivative of strain 300 which does not nodulate, appears to have suffered a deletion in the largest of the three plasmids which are usually visible when plasmid preparations are subjected to agarose gel electrophoresis. Strain 6015 also appears to have lost the ability to fix nitrogen, and genetic evidence supports the view that strain 6015 has lost some genes involved in symbiosis (Buchanan-Wollaston et al., 1980).

Surprisingly, strain 1062, a separate derivative of strain 300 which did not differ symbiotically from its parent, had a band of molecular weight smaller than any of those in strain 300 . Possibly, the fastest-migrating band of strain 300 actually comprises two plasmid species with indistinguishable mobilities (this band was relatively brighter than the corresponding band in strain 1062) and one of these plasmids has suffered a spontaneous deletion in strain 1062.

When the determinant of medium bacteriocin production pRL1JI was transferred between strains an extra plasmid with a molecular weight of about $130 \times 10^{6}$ was inherited. Similarly, strains carrying pRL4JI had acquired in most cases a single extra band of molecular weight about $160 \times 10^{6}$.

Plasmid rearrangement was observed in a strain 1062 transconjugant which had received the determinant of medium bacteriocin production pRL3JI from field isolate 306 . The new plasmid band in this transconjugant did not correspond to any in strain 306 and, furthermore, one of the plasmids of strain 1062 appeared to have been replaced by a new, larger species. Without more detailed analysis we can only speculate on the nature of these apparently recombinational events.

When the determinants of medium bacteriocin production pRL1JI, pRL3JI or pRL4JI were transferred to derivatives of strain 300 , the transconjugants no longer made the small bacteriocin produced by strain 300 (Hirsch, 1979; Brewin et al., 1980). Since there was no evidence for the loss of a plasmid from transconjugants, it is more likely that the loss of the ability to produce small bacteriocin is due to the repression of this property by the incoming plasmids, rather than to the elimination of its determinants (although the possibility of replacement of one plasmid species by another of the same size cannot be ruled out by the evidence presented here).

The three bacteriocinogenic plasmids studied here - pRL1JI, pRL3JI and pRL4JI have previously been shown to have many properties in common (Hirsch, 1979; Brewin 
et al., 1980). They specify the production of medium bacteriocins that are apparently similar; they repress (or eliminate) the production of small bacteriocin by strains that contain them; they transfer between strains at high frequencies; they mobilize chromosomal genes at low frequencies; they cannot co-exist within the same cell without apparently undergoing interplasmid recombination. However, an important difference between these three plasmids is that, unlike the other two, the plasmid pRL1JI carries a number of symbiotic gene functions capable of restoring several mutations of strain 300 derivatives (Nod- and $\mathrm{Fix}^{-}$) to a wild-type phenotype (Brewin et al., 1980). Despite these extra symbiotic gene functions specified by pRLIJI, this plasmid appears to be smaller than either pRL3JI or pRL4JI. However, it is not known what fraction of pRL1JI is concerned with the specification of symbiotic gene functions not present on pRL3JI or pRL4JI, nor indeed what other gene functions (apart from bacteriocin production) might be specified by any of these large plasmids.

Although the plasmids pRL3JI and pRL4JI do not themselves specify genes for nodulation and fixation that are absent from the $\mathrm{Nod}^{-}$strain 6015 , they were found to mobilize these alleles at relatively high frequency in crosses from a wild-type donor (Brewin et al., 1980). Presumably this transfer was the result of selected inter-plasmid recombination. In the present physical study, we have shown that, at least in the case of pRL3JI, plasmid rearrangements occurred after transfer of the bacteriocinogenic plasmid into a new host. Perhaps these phenomena are to be expected if one or more plasmids contain several similar DNA sequences; however, such interactions are likely to make the physical and genetic analysis of Rhizobium plasmids rather more complicated than it otherwise might be.

We are grateful to Professor D. A. Hopwood and Dr J. E. Beringer for their criticism of the manuscript.

\section{REFERENCES}

Berg, D., Davies, J., Allet, B., Rochaix, J. D. (1975). Transposition of R-factor genes to bacteriophage $\lambda$. Proceedings of the National Academy of Sciences of the United States of America 72, 3628-3632.

BERINGER, J. E. (1974). R factor transfer in Rhizobium leguminosarum. Journal of General Microbiology 84, 188-198.

Beringer, J. E., Beynon, J. L., Buchanan-Wollaston, A. V. \& Johnston, A. W. B. (1978a). Transfer of the drug-resistance transposon $\operatorname{Tn} 5$ to Rhizobium. Nature, London 276, 633-634.

Beringer, J. E., Hoggan, S. A. \& Johnston A. W. B. $(1978 b)$. Linkage mapping in Rhizobium leguminosarum by means of $\mathbf{R}$ plasmid-mediated recombination. Journal of General Microbiology 104, 201-207.

Brewin, N. J., Beringer, J. E., Buchanan-WollaSTON, A. V. \& Hirsch, P. R. (1980). Transfer of symbiotic genes with bacteriocinogenic plasmids in Rhizobium leguminosarum. Journal of General Microbiology 116, 261-270.

Buchanan-Wollaston, A. V., Beringer, J. E., BREWIN, N. J., HiRSCH, P. R. \& JOHNSTON, A. W. B. (1980). Isolation of symbiotically defective mutants in Rhizobium leguminosarum by insertion of the transposon Tn5 into a transmissible plasmid. Molecular and General Genstics 178, 185-190.

Casse, F., Boucher, C., Julliot, J. S., Michel, M. \&DÉNARIf́, J. (1979). Identification and characterization of large plasmids in Rhizobium meliloti using agarose gel electrophoresis. Journal of General Microbiology 113, 229-242.

Currier, T. C. \& Nester, E. W. (1976). Isolation of covalently closed circular DNA of high molecular weights from bacteria. Analytical Biochemistry 76, 431-441.

HANSEN, J. B. \& Olsen, R. H. (1978). Isolation of large bacterial plasmids and characterization of the $\mathbf{P 2}$ incompatibility group plasmids pMG1 and pMG5. Journal of Bacteriolog): 135, 227-238.

HiRsCh, P. R. (1979). Plasmid-determined bacteriocin production by Rhizobium leguminosarum. Journal of General Microbiology 113, 219-228.

Holsters, M., Silva, B., Genetello, C., Engler, G., Van Vliet, F., de Block, M., Villaroel, R., ivan Montagu, M. \& Schell, J. (1978). Spontaneous formation of cointegrates of the oncogenic Ti-plasmid and the wide-host-range of P-plasmid RP4. Plasmid 1, 456-467.

Johnston, A. W. B. \& BERINGER, J. E. (1975). Identification of the Rhizobium strains in pea root nodules using genetic markers. Journal of General Microbiology 87, 343-350.

Johnston, A. W. B. \& Beringer, J. E. (1976). Pea root nodules containing more than one Rhizobium species. Nature, London 263, 502-504.

Johnston, A. W. B., Beynon, J. L., BuchananWollaston, A. V., Setchell, S. M., Hirsch, P. R. \& Beringer, J. E. (1978). High frequency transfer of nodulating ability between strains and species of Rhizobium. Nature, London 276, 635-636.

MIC 120 
Josey, D. P., Beynon, J. L., Johnston, A. W. B. \& BERINGER, J. E. (1979). Strain identification in Rhizobium using intrinsic antibiotic resistance. Journal of Applied Bacteriology 46, 343-350.

Ledeboer, A. M., Krol, A. J. M., Dons, J. J. M., Spier, F., SChILPERoort, R. A., Zaenen, I., VAN LAREbeke, N. \& Schell, J. (1976). On the isolation of $\mathrm{Ti}$ plasmid from Agrobacterium tumefaciens. Nucleic Acids Research 3, 449463.

Nuti, M. P., Ledeboer, A. M., LePIDI, A. A. \& SCHILPEROORT, R. A. (1977). Large plasmids in different Rhizobium species. Journal of General Microbiology 100, 241-248.

Nuti, M. P., Lepidi, A. A., Prakash, R. K., SCHIlperoort, R. A. \& CANNON, F. C. (1979). Evidence for nitrogen fixation (nif) genes on indigenous Rhizobium plasmids. Nature, London 282, 533-535.

PaIN, A. N. (1979). Symbiotic properties of antibiotic-resistant and auxotrophic mutants of Rhizobium leguminosarum. Journal of Applied Bacteriology 47, 53-64.
Prakash, R. K., HooykaAs, P. J. J., Ledeboer, A. M., KiJne, J., Schilperoort, R. A., Nuti, M. P., Lepidi, A. A., Casse, F., Boucher, C., Julliot, J. S. \& DénARIÉ, J. (1980). Detection, isolation and characterization of large plasmids in Rhizobium. In Proceedings of the Third International Symposium on Nitrogen Fixation, 1979. Edited by W. H. Orme-Johnson \& W. E. Newton. Madison: University Park Press (in the Press).

Ruvkun, G. B. \& Ausubel, F. M. (1980). Interspecies homology of nitrogenase genes. Proceedings of the National Academy of Sciences of the United States of America 77, 191-195.

Watson, B., Currier, T. C., Gordon, M. P., Chilton, M. D. \& Nester, E. W. (1975). Plasmid required for virulence of Agrobacterium tumefacions. Journal of Bacteriology 123, 255-264.

ZaEnen, I., vaN LARebeKe, N., Teuchy, H., vaN Montagu, M. \& Schell, J. (1974). Supercoiled circular DNA in crown-gall inducing Agrobacterium strains. Journal of Molecular Biology 86, 109-127. 